\title{
Regulation of electrolyte transport across cultured endometrial epithelial cells by prolactin
}

\author{
Chatsri Deachapunya, Sutthasinee Poonyachoti ${ }^{1}$ and Nateetip Krishnamra ${ }^{2,3}$ \\ Department of Physiology, Faculty of Medicine, Srinakharinwirot University, Sukhumvit 23, Wattana, Bangkok 10110, Thailand \\ ${ }^{1}$ Department of Physiology, Faculty of Veterinary Science, Chulalongkorn University, Henri-Dunant Road, Bangkok 10330, Thailand \\ ${ }^{2}$ Department of Physiology and ${ }^{3}$ Consortium for Calcium and Bone Research, Faculty of Science, Mahidol University, Rama VI Road, Bangkok 10400, Thailand \\ (Correspondence should be addressed to C Deachapunya; Email: chatsri@swu.ac.th)
}

\begin{abstract}
The effect of prolactin (PRL) on ion transport across the porcine glandular endometrial epithelial cells was studied in primary cell culture using the short-circuit current technique. Addition of $1 \mu \mathrm{g} / \mathrm{ml} \mathrm{PRL}$ either to the apical solution or to the basolateral solution produced a peak followed by a sustained increase in Isc, but with a lesser response when PRL was added apically. Basolateral addition of PRL increased the Isc in a concentrationdependent manner with a maximum effect at $1 \mu \mathrm{g} / \mathrm{ml}$ and an effective concentration value of $120 \mathrm{ng} / \mathrm{ml}$. The PRLstimulated Isc was significantly reduced by pretreatment with an apical addition of 5-nitro-2-(3-phenylpropylamino) benzoic acid $(200 \mu \mathrm{M})$, diphenylamine-2-carboxylic acid $(1 \mathrm{mM})$ or 4,4'-diisothiocyanatostilbene-2,2'-disulfonic acid $(200 \mu \mathrm{M})$, $\mathrm{Cl}^{-}$channel blockers, but not by amiloride $(10 \mu \mathrm{M}), \mathrm{a} \mathrm{Na}^{+}$ channel blocker. In addition, pretreatment with bumetanide
\end{abstract}

$(200 \mu \mathrm{M}), \mathrm{a} \mathrm{Na}^{+}-\mathrm{K}^{+}-2 \mathrm{Cl}^{-}$cotransporter inhibitor, in the basolateral solution significantly reduced the PRL-stimulated Isc. Replacement of $\mathrm{Cl}^{-}$or $\mathrm{HCO}_{3}^{-}$in the bathing solutions also decreased the Isc response to PRL. Pretreatment of the monolayer with AG490 $(50 \mu \mathrm{M})$, an inhibitor of JAK2 activity significantly inhibited the PRL-induced increase in Isc. Western blot analysis of the porcine endometrial epithelial cells revealed the presence of short isoform of PRL receptor (PRLR-S) that could be regulated by $17 \beta$-estradiol. The results of this investigation showed that PRL acutely stimulated anion secretion across the porcine endometrial epithelial cells possibly through PRLR-S present in both apical and basolateral membranes. The PRL response appeared to be mediated by the JAK2-dependent pathway.

Journal of Endocrinology (2008) 197, 575-582

\section{Introduction}

Endometrial epithelial cells play an important role in the regulation of fluid and electrolyte volume and composition within the uterine cavity, providing an optimal intrauterine environment for implantation and embryo development. The transport-related activities of the surface and glandular epithelial cells have been shown to be regulated by several hormones, growth factors, cytokines, and a number of signaling molecules. Electrophysiological studies of cultured human endometrial epithelial cells (Matthews et al. 1993) and the intact porcine endometrial epithelium (Vetter \& O'Grady 1996) have provided direct evidence for the regulation of $\mathrm{Na}^{+}$absorption and $\mathrm{K}^{+}$secretion. In the primary culture of mouse and porcine endometrial epithelial cells, prostaglandins (PGs) especially PGE2, adrenaline, ATP, and UTP were found to activate anion secretion (Chan et al. 1997, Fong et al. 1998, Deachapunya \& O'Grady 1998, Palmer-Densmore et al. 2002). These epithelial cells also exhibited $\mathrm{Na}^{+}$ transport that was activated by insulin and insulin-like growth factor, and inhibited by epidermal growth factor (Deachapunya et al. 1999, Deachapunya \& O'Grady 2001).

Prolactin (PRL) is synthesized and secreted from the anterior pituitary gland, as well as the extrapituitary tissues including myometrium, deciduas, and mammary epithelial cells (Freeman et al. 2000). It exerts a wide variety of biological actions, such as the regulation of water and electrolyte balance, growth of mammary gland, milk production, and secretion. Recently, PRL has been reported to stimulate the intestinal $\mathrm{Ca}^{2+}$ absorption (Jantarajit et al. 2007), especially under conditions of high calcium demand such as pregnancy and lactation (Charoenphandhu \& Krishnamra 2007).

In human endometrium, PRL receptors (PRL-R) and its mRNA have been identified in glandular epithelial and stromal cells (Jabbour et al. 1998, Tseng \& Zhu 1998). PRL-R belongs to the superfamily of the cytokine class-1 receptor (Kelly et al. 1991). Several isoforms, i.e. short, intermediate, and long isoforms and the soluble PRL-binding protein have been identified in many tissues (Clevenger \& Kline 2001). Binding of PRL to its transmembrane receptors induces receptor 
dimerization, tyrosine phosphorylation, and activation of the JAK, which leads to phosphorylation of other associated regulatory proteins especially the STAT proteins. The phosphorylated STAT proteins dimerize and translocate to the nucleus to bind to the PRL-responsive genes, resulting in target gene transcription and biological responses. Other signaling pathways involving mitogen-activated protein kinase (MAPK), insulin-receptor substrate (IRS-1), phosphoinositide 3 (PI-3) kinase, PLC, PKC, and intracellular $\mathrm{Ca}^{2+}$ have also been reported to mediate PRL actions (Bole-Feysot et al. 1998, Gubbay et al. 2002).

Although PRL is known as an important regulator of water and electrolyte transport in lower vertebrates (Bern 1975, Sakamoto \& McCormick 2006), there were very few reports on its transport-related effect in the mammalian epithelial cells. Several studies using the everted intestinal sac technique have demonstrated the stimulatory effect of PRL on fluid and $\mathrm{NaCl}$ absorption in the rat, hamster, and guinea pig jejunum, but not in guinea pig ileum or rat colon (Mainoya et al. 1974). In the rabbit mammary glands, PRL decreased epithelial membrane permeability to sucrose, suggesting a decrease in the permeability of the tight junction (Linzell et al. 1975). From the studies using the mouse mammary epithelial cells grown on floating collagen gels, PRL treatment for 3 days was found to increase the short-circuit current (Isc) and transepithelial potential difference (PD), which indicated an increase in net active $\mathrm{Na}^{+}$absorption, probably with some $\mathrm{Cl}^{-}$secretion (Bisbee et al. 1979). In the mouse mammary epithelial cell line HC11, PRL acutely increased $\mathrm{Cl}^{-}$transport through the JAK-STAT system (Selvaraj et al. 2000). Eventhough PRL seemed to play an important role in the regulation of transepithelial ion transport in a variety of epithelia, its effect on the ion transport function of the endometrial epithelium has not been investigated. Since we have previously shown that the primary cultured porcine endometrial epithelial cells possessed the transport machinery capable of $\mathrm{Na}^{+}$ absorption and $\mathrm{Cl}^{-}$secretion (Deachapunya \& O'Grady 1998, Deachapunya et al. 1999), the objectives of the present study were to investigate the regulatory mechanism of PRL on the ion transport across these epithelial cells.

\section{Materials and Methods}

\section{Materials}

PRL, insulin, amiloride, 5-nitro-2-(3-phenylpropylamino) benzoic acid (NPPB), diphenylamine-2-carboxylic acid (DPC), 4,4'-diisothiocyanatostilbene-2,2'-disulfonic acid (DIDS), bumetanide, acetazolamide, PGE2, 8-chloro-phenylthio- $3^{\prime}, 5^{\prime}$-cyclicmonophosphate (8cpt-cAMP), non-essential amino acids, and high-purity grade salts were obtained from Sigma Chemical Co. Dulbecco's modified Eagle's medium (DMEM), Dulbecco's PBS (DPBS), fetal bovine serum (FBS), collagenase (type 1), kanamycin, penicillin-streptomycin, and fungizone were purchased from Gibco (Grand Island, NY).

\section{Cell isolation and culture}

Porcine uterine tissues collected from 5- to 6-month-old pig were obtained from the Metropolitan slaughterhouse, Klongtoey, Bangkok, under the supervision of the Department of Livestock Development, Ministry of Agriculture and Cooperatives, Thailand. The tissue was placed in an ice-cold porcine Ringer solution containing $(\mathrm{mM}): 130 \mathrm{NaCl}, 6 \mathrm{KCl}, 3$ $\mathrm{CaCl}_{2}, 0.7 \mathrm{MgCl}_{2}, 20 \mathrm{NaHCO}_{3}, 0.3 \mathrm{NaH}_{2} \mathrm{PO}_{4}$, and 1.3 $\mathrm{Na}_{2} \mathrm{HPO}_{4}(\mathrm{pH} 7 \cdot 4)$. After removal of the serosal muscle layer, the tissue fragments were cut into small pieces and digested overnight with collagenase. The epithelial glands were then isolated as described previously (Deachapunya \& O'Grady 1998), and suspended in DMEM supplemented with $3.7 \mathrm{~g} / 1$ $\mathrm{NaHCO}_{3}, 10 \%$ FBS, $850 \mathrm{nM}(5 \mu \mathrm{g} / \mathrm{ml})$ insulin, $1 \%$ nonessential amino acid, $5 \mu \mathrm{g} / \mathrm{ml}$ fungizone, $100 \mathrm{U} / \mathrm{ml}$ penicillin, $100 \mu \mathrm{g} / \mathrm{ml}$ streptomycin, and $100 \mu \mathrm{g} / \mathrm{ml}$ kanamycin (standard media). They were then plated onto the cell culture dishes and incubated at $37^{\circ} \mathrm{C}$ in a humidified atmosphere of $5 \% \mathrm{CO}_{2}$ in air. Culture medium was changed after $24 \mathrm{~h}$ and then every 2-3 days. After $80 \%$ confluence (within 2-3 days), the epithelial cells were subcultured onto $24 \mathrm{~mm}\left(4.5 \mathrm{~cm}^{2}\right)$ transparent permeable membrane filters (Costar, Cambridge, MA, USA). Using this method of isolation, the purity of epithelial cells was greater than $90 \%$ as assessed by staining the isolated cells with cytokeratin (Deachapunya \& O'Grady 1998). Cell monolayers were fed every 2 days and maintained in the standard media for about 7 days before the beginning of the experiment.

\section{Measurement of electrical parameters}

Before studying ion transport, the transepithelial resistance of the cell monolayer was measured with an epithelial voltohmmeter (EVOM) coupled to $\mathrm{Ag} / \mathrm{AgCl}$ 'chopstick' electrodes (World Precision Instruments, Serasota, FL, USA). Monolayer with high resistance $\left(\approx 3000 \Omega \mathrm{cm}^{2}\right)$ was then mounted in Ussing Chamber, bathed in both sides with the standard porcine Ringer solution, which was maintained at $37^{\circ} \mathrm{C}$ and bubbled with $95 \% \mathrm{O}_{2}-5 \% \mathrm{CO}_{2}$. Transepithelial PD and Isc were measured with the use of voltage-clamp circuitry (EVC4000, World Precision Instruments) with $\mathrm{Ag} / \mathrm{AgCl}$ electrodes connected to the bathing solution via agar bridges. Tissue conductance $(G)$ was calculated using Ohm's law $(\mathrm{G}=\mathrm{Isc} / \mathrm{PD})$. The monolayer was continuously short circuited, except for a brief interval of open-circuited readings for PD measurement before and after adding any chemical. Data from the voltage clamp were connected to a MacLab 4S A/D converter and recorded with a $400 \mathrm{MHz}$ PowerPC Macintosh. After mounting, the cell monolayer was equilibrated for at least $20 \mathrm{~min}$ to achieve a stable Isc before addition of chemicals. Positive Isc corresponded to the movement of anions in the serosal to mucosal direction or the movement of cations in the mucosal to serosal direction or a combination of both. In the anion replacement experiments, gluconate salts were substituted for chloride 
and HEPES were substituted for bicarbonate. The experiment under $\mathrm{HCO}_{3}^{-}$free condition was performed in the presence of $100 \mu \mathrm{M}$ acetazolamide and bubbled with $100 \% \mathrm{O}_{2}$.

\section{Western blot analysis}

Porcine endometrial epithelial cells seeded in the $100 \mathrm{~mm}$ cell culture dish were allowed to grow in the standard medium up to $80 \%$ confluence. In some experiments, the medium was switched to the serum-free and phenol red-free DMEM alone or supplemented with $10^{-8}$ M $17 \beta$-estradiol for $48 \mathrm{~h}$. Cells were then harvested and suspended in lysis buffer containing $50 \mathrm{mM}$ Tris- $\mathrm{HCl}, 1 \% \mathrm{NP}-40,0 \cdot 25 \%$ sodium deoxycholate, $150 \mathrm{mM} \mathrm{NaCl}, 1 \mathrm{mM}$ EGTA, $1 \mathrm{mM}$ phenylmethylsulfonyl fluoride, $20 \mu \mathrm{g}$ aprotinin, and $1 \mathrm{mM} \mathrm{NaF}$ ( $\mathrm{pH}$ 7•4). The supernatant was collected and protein concentrations were determined using the BCA protein assay kit (Pierce Biotechnology, Inc., Rockford, IL, USA). Protein samples $(20 \mu \mathrm{g})$ were separated by $10 \%$ SDS-PAGE and electrically transferred to a polyvinylidene difluoride membrane (Hybond-P, Amersham Biosciences) in Tris-glycine buffer. Blotted membranes were washed and then blocked with $5 \%$ nonfat powdered milk in Tris-buffered saline for $4 \mathrm{~h}$ at room temperature with constant agitation. The membrane was incubated overnight at $4{ }^{\circ} \mathrm{C}$ with $1 \mu \mathrm{g} / \mathrm{ml}$ primary antibody, which is anti-rat PRL receptor monoclonal antibody generated against the extracellular domain of PRL receptor (clone U5, Affinity BioReagents). The membrane was then washed and incubated for $1 \mathrm{~h}$ at room temperature with a 1:10 000 horseradish peroxidase (HRP)-conjugated goat anti-mouse secondary antibody (Zymed Laboratories Inc., San Francisco, CA, USA). After washing, the immunoreactive protein bands were visualized using the enhanced chemiluminescence (ECL) detection system (Santa Cruz Biotechnology Inc., Santa Cruz, CA, USA) according to the manufacturer's instructions. The membranes were exposed to film (Hyperfilm-ECL, Amersham Biosciences) for adequate duration to visualize the chemiluminescent bands. To confirm equal loading, the membranes were stripped and reprobed with a 1:300 000 anti- $\beta$-actin monoclonal antibody (clone AC-15, Sigma Co.) followed by a 1:10 000 HRP-conjugated anti-mouse antibody. The intensity of the protein bands was determined using densiotometry analysis (Scion Image; Scion Cooperation, Frederick, MD, USA). Band intensity of the PRL-R from each treatment was normalized to the $\beta$-actin intensity and expressed as the PRL-R/ $\beta$-actin ratio.

\section{Data analyses}

All values are presented as mean \pm S.E.M. and $n$ is the number of monolayers from at least three different uterine tissue cultures. The differences between control and experimental means were analyzed using a Student's $t$-test or ANOVA where appropriate. The difference between treatment and control means following a significant ANOVA was identified by Dunnett's test (Prism 3.0, GraphPad Software, Inc., San Diego, CA,
USA). A value of $P<0 \cdot 05$ was considered statistically significant. The effective concentration $\left(\mathrm{EC}_{50}\right)$ value was determined using a four-parameter logistic function to fit the data (Prism 3.0; GraphPad Software Inc.).

\section{Results}

\section{Effect of PRL on Isc}

Under basal condition, after an equilibrating period of $30 \mathrm{~min}$, the porcine endometrial epithelial monolayer exhibited average Isc, PD (lumen negative), and tissue conductance of $30.68 \pm 2 \cdot 49 \mu \mathrm{A},-27 \cdot 22 \pm 3.89 \mathrm{mV}$, and $1 \cdot 47 \pm 0 \cdot 25 \mathrm{mS}(n=17)$ respectively. Addition of $1 \mu \mathrm{g} / \mathrm{ml}$ PRL to the apical or basolateral solution produced an increase in Isc that reached a peak within 2-3 min before decreasing slightly and was maintained at a level above baseline (Fig. 1A). In some experiments, the PRL-stimulated Isc gradually decreased to the baseline level. The peak Isc response to apical addition of $1 \mu \mathrm{g} / \mathrm{ml}$ PRL was $3.45 \pm 0.94 \mu \mathrm{A}(n=4)$, while the subsequent basolateral addition of 1 and $5 \mu \mathrm{g} / \mathrm{ml}$ PRL led
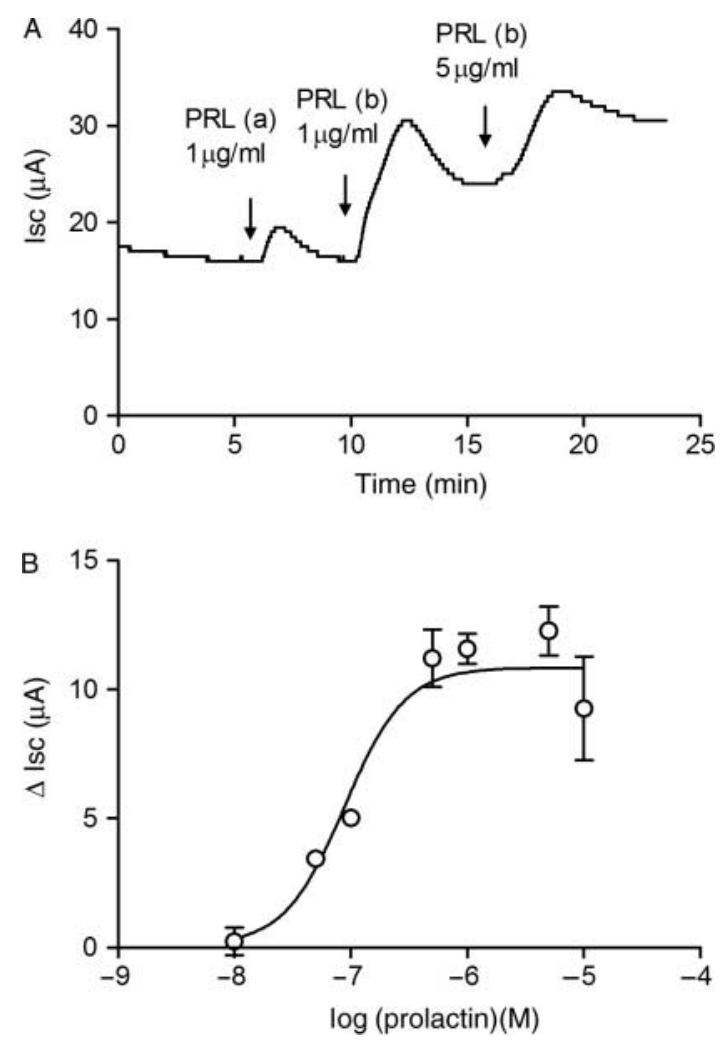

Figure 1 Effect of PRL on the basal Isc in the endometrial epithelial monolayers. (A) A representative Isc tracing responded to an addition of $1 \mu \mathrm{g} / \mathrm{ml}$ PRL to (a) the apical solution followed by 1 and $5 \mu \mathrm{g} / \mathrm{ml} \mathrm{PRL}$ added to (b) the basolateral solution. (B) Concentration-response relationships showing the increase in Isc following basolateral treatment with various concentrations of PRL. The $\mathrm{EC}_{50}$ value was $120 \mathrm{ng} / \mathrm{ml}(n=6)$. 
to a peak Isc of $11.00 \pm 0.98 \mu \mathrm{A}(n=17)$ and $14.36 \pm$ $1 \cdot 37 \mu \mathrm{A}(n=12)$ respectively. Basolateral addition of PRL increased the Isc in a concentration-dependent manner with a maximum response with $1 \mu \mathrm{g} / \mathrm{ml} \mathrm{PRL}$ and a half maximum $\mathrm{EC}_{50}$ value of $120 \mathrm{ng} / \mathrm{ml}(n=6$, Fig $1 \mathrm{~B})$.

\section{Ionic basis of the PRL-stimulated Isc}

To determine the ionic basis of the Isc response induced by PRL, we examined the effect of PRL in the presence of pharmacological ion channel blockers and ion substitution solutions. An apical application of the $\mathrm{Na}^{+}$channel blocker amiloride at $10 \mu \mathrm{M}$ inhibited the basal Isc by 35\% (Fig. 2A). However, it did not affect the Isc response induced by PRL $(1 \mu \mathrm{g} / \mathrm{ml})$, which was $12 \cdot 21 \pm 1 \cdot 39 \mu \mathrm{A}(n=5)$, when compared with the control value of $11 \cdot 44 \pm 1 \cdot 22 \mu \mathrm{A}(n=12)$ (Fig. $2 \mathrm{E})$. By contrast, the PRLstimulated Isc was significantly decreased in the presence of $\mathrm{Cl}^{-}$ channel blockers, NPPB, DPC, and DIDS in the apical solution. NPPB and DPC have been widely used to block CFTR,
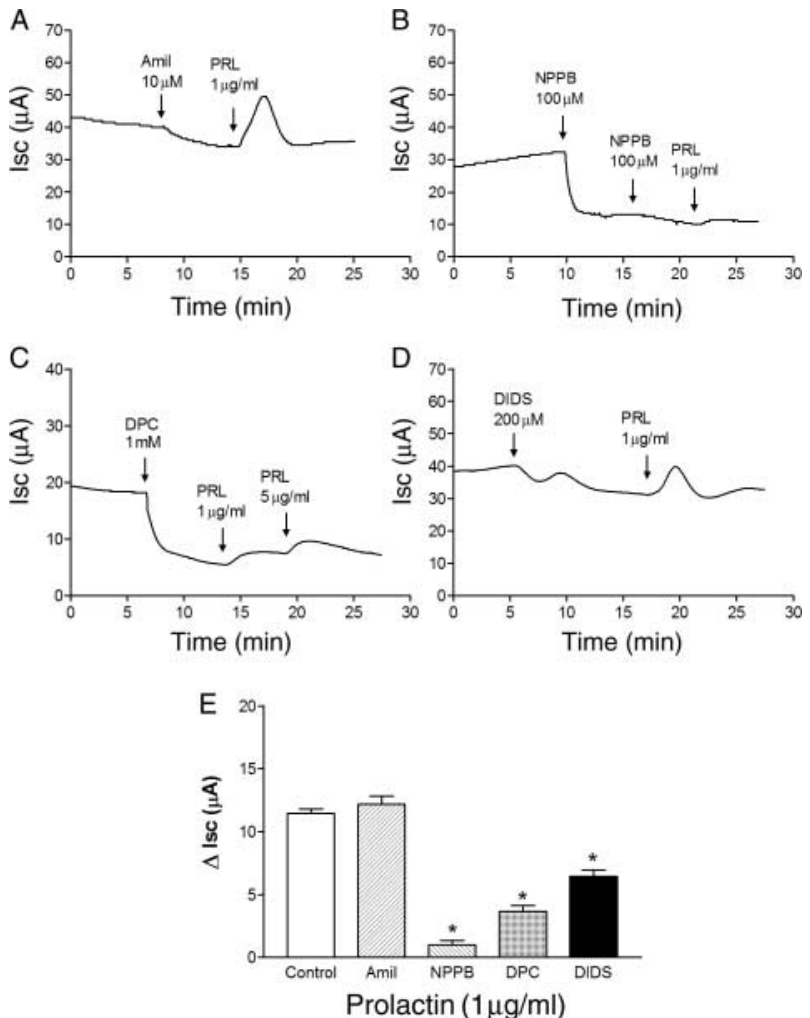

Figure 2 Effect of ion channel blockers on the PRL-stimulated Isc. (A) A representative Isc tracing showing that an apical addition of amiloride (Amil, $10 \mu \mathrm{M}$ ) produced a small decrease in basal Isc. A subsequent addition of PRL $(1 \mu \mathrm{g} / \mathrm{ml})$ into the basolateral solution produced an increase in Isc. (B) An apical addition of NPPB $(100 \mu \mathrm{M}),(\mathrm{C}) \mathrm{DPC}(1 \mathrm{mM})$, or (D) DIDS $(200 \mu \mathrm{M})$ decreased the basal Isc and reduced the PRL response. (E) Bar graph illustrating the average maximal increases in Isc response produced by prolactin alone (control) and in the presence of amiloride, NPPB, DPC, or DIDS. Values represent means \pm S.E.M. ${ }^{*} P<0 \cdot 01$ when compared with the control value by ANOVA.
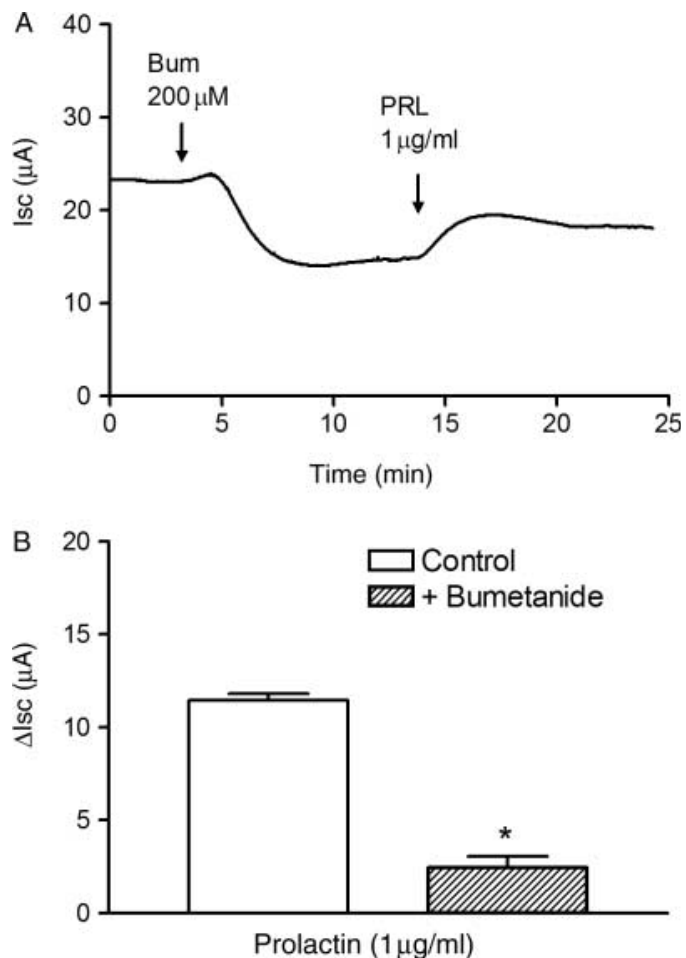

Figure 3 Effect of $\mathrm{Na}^{+}-\mathrm{K}^{+}-2 \mathrm{Cl}^{-}$cotransporter blockers on the PRL-stimulated Isc. (A) A representative Isc tracing showing that a basolateral addition of bumetanide $(200 \mu \mathrm{M})$ produced a decrease in basal Isc. A subsequent addition of PRL $(1 \mu \mathrm{g} / \mathrm{ml})$ into the basolateral solution produced a slightly increase in Isc. (B) Bar graph illustrating the average maximal increases in Isc response produced by prolactin alone (control) and in the presence of bumetanide. Values represent means \pm s.E.M. ${ }^{*} P<0 \cdot 01$ when compared with the control value by Student's $t$-test.

whereas DIDS blocks the $\mathrm{Ca}^{2+}$-activated $\mathrm{Cl}^{-}$channels with no effect on the activity and conductance of CFTR (Anderson et al. 1992). As shown in Fig. $2 \mathrm{~B}$ and C, pretreatment with $100 \mu \mathrm{M}$ NPPB or $1 \mathrm{mM}$ DPC reduced the basal Isc by 60 and $75 \%$ and decreased the Isc response to PRL to $1 \cdot 00 \pm 0 \cdot 71 \mu \mathrm{A}$ $(n=4)$ and $3.65 \pm 0.95 \mu \mathrm{A}(n=5)$ respectively. An apical addition of $200 \mu \mathrm{M}$ DIDS reduced the basal Isc by $17 \%$ and reduced the Isc response to PRL to $6 \cdot 43 \pm 1 \cdot 20 \mu \mathrm{A}(n=4)$ (Fig. 2D). In addition, pretreatment with $200 \mu \mathrm{M}$ bumetanide, a $\mathrm{Na}^{+}-\mathrm{K}^{+}-2 \mathrm{Cl}^{-}$cotransporter inhibitor, in the basolateral solution abolished most of the PRL-induced increase in Isc from $11 \cdot 44 \pm 1 \cdot 22 \mu \mathrm{A}(n=12)$ to $2 \cdot 48 \pm 1 \cdot 17 \mu \mathrm{A}(P<0 \cdot 01$, $n=4$ ) (Fig. 3). Replacement of $\mathrm{Cl}^{-}$or $\mathrm{HCO}_{3}^{-}$in both the apical and the basolateral solutions markedly reduced the maximal Isc response to $1 \mu \mathrm{g} / \mathrm{ml}$ PRL to $1.63 \pm 1.06 \mu \mathrm{A}$ $(n=5)$ and $0 \cdot 9 \pm 0 \cdot 3 \mu \mathrm{A}(n=3)$ respectively (Fig. 4$)$.

\section{Intracellular signaling pathways of PRL-induced increase in Isc}

The major signaling pathway involved in PRL action is the JAK-STAT pathway which was shown to mediate $\mathrm{Cl}^{-}$ 


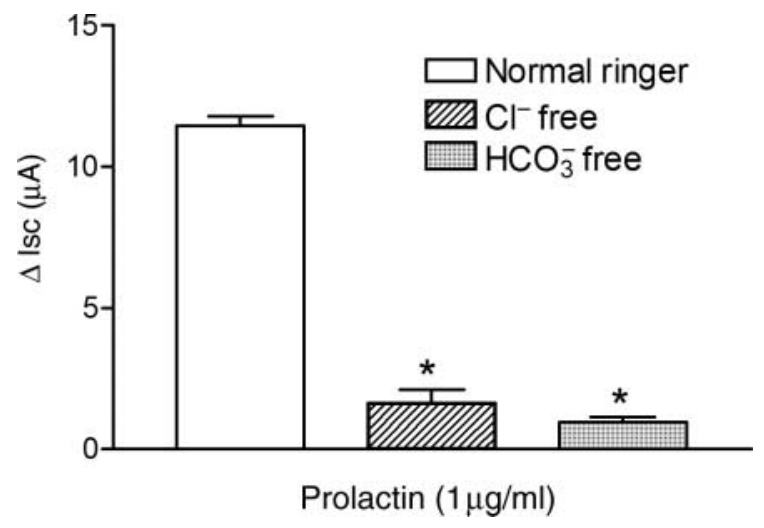

Figure 4 Effects of anion substitution on the maximal Isc response to PRL. In standard Ringer's solution, PRL $(1 \mu \mathrm{g} / \mathrm{ml})$ produced a mean increase in Isc of $11.44 \pm 1.22 \mu \mathrm{A}(n=12)$. Replacement of $\mathrm{Cl}^{-}$and $\mathrm{HCO}_{3}^{-}$in both the apical and basolateral solutions significantly inhibited the maximal Isc response to PRL by $86 \%(n=4)$ and $92 \%$ $(n=4)$ respectively. ${ }^{*} P<0 \cdot 01$ when compared with the control value by ANOVA.

secretion in the mammary cell line, HC11 (Selvaraj et al. 2000). Phosphorylations of JAK2, STAT1, and STAT5 have been demonstrated in response to PRL stimulation $(200 \mathrm{ng} / \mathrm{ml}$ ) in human endometrium (Jabbour et al. 1998). To determine whether JAK2 was involved in the PRL-induced increase in Isc, we examined the effect of AG490, an inhibitor of JAK2 activity, on PRL action. As shown in Fig 5A, pretreatment with $50 \mu \mathrm{M}$ AG490, added to both the basolateral and apical solutions, reduced the basal Isc by $55 \%$ from $26 \cdot 21 \pm 4 \cdot 99$ to $11 \cdot 75 \pm 4 \cdot 01 \mu \mathrm{A}(P<0 \cdot 01, n=5)$. Sequential additions of 1 and $5 \mu \mathrm{g} / \mathrm{ml}$ PRL slightly increased the Isc response by $3 \cdot 70 \pm 3 \cdot 09$ and $0 \cdot 80 \pm 0 \cdot 66 \mu \mathrm{A}(n=5)$ respectively. However, the presence of AG490 did not affect the Isc response to $100 \mu \mathrm{M} 8 \mathrm{cpt}$-cAMP, which was $22 \cdot 80 \pm$ $2 \cdot 14 \mu \mathrm{A}(n=4)$ when compared with the control value of $18.99 \pm 1.59 \mu \mathrm{A} \quad(n=5)$, but slightly decreased the Isc response to $3 \mu \mathrm{M}$ PGE2 to $12 \cdot 08 \pm 0 \cdot 87 \mu \mathrm{A}(n=4)$, which was not statistically significant from that of control $(16 \cdot 84 \pm$ $1.55 \mu \mathrm{A}, n=7$, Fig. $5 \mathrm{~B})$.

\section{Expression of $P R L$ receptor}

To confirm the functional significance of PRL in the regulation of ion transport, the expression of PRL-R was determined using western blot analysis. A representative western blot as presented in Fig. 6A demonstrated the presence of proteins with an approximate molecular mass of $36 \mathrm{kDa}$ in porcine endometrial epithelial cells as well as in the human mammary gland cancer cell MCF-7 and human endometrial cancer cell RL-95. The $36 \mathrm{kDa}$ protein band corresponded to the short form of PRL-R. Replacement of the standard medium of the endometrial epithelial cells with the serum-free and phenol red-free medium reduced the expression of the protein, whereas addition of $17 \beta$-estradiol $\left(10^{-8} \mathrm{M}\right)$ in the serum-free medium up-regulated the PRL
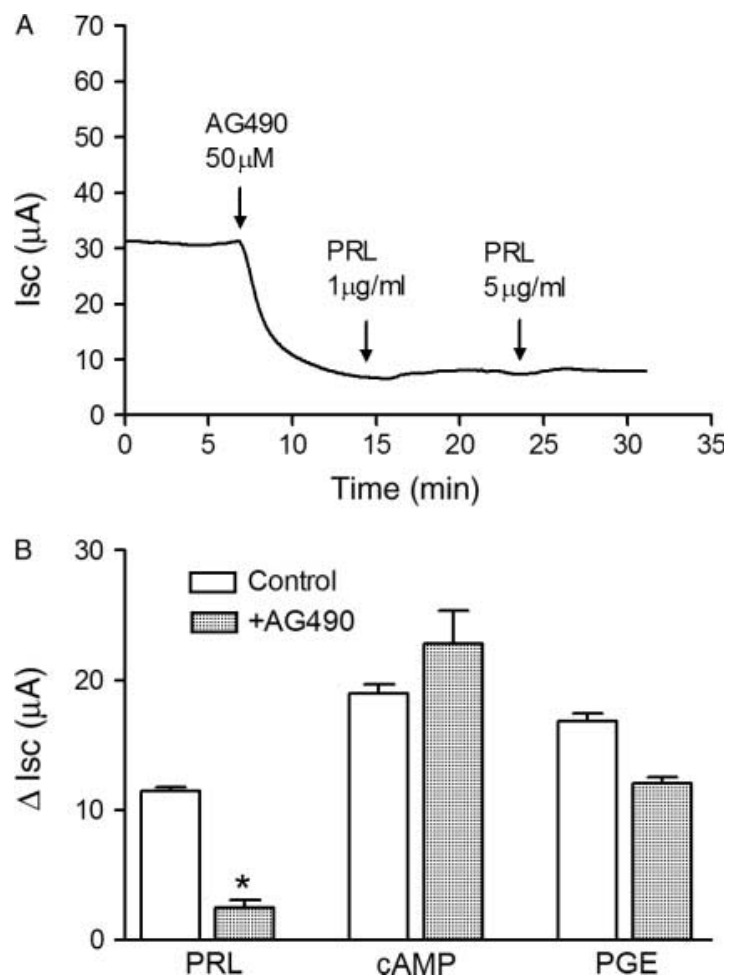

Figure 5 Effect of JAK2 activity inhibitor on the PRL-stimulated Isc. (A) A representative Isc tracing showing that an addition of AG490 $(50 \mu \mathrm{M})$, an inhibitor of JAK2 activity, to both apical and basolateral solutions completely inhibited both basal and PRL-induced increase in Isc. (B) Bar graph illustrating the average maximal increases in Isc response produced by PRL $(1 \mu \mathrm{g} / \mathrm{ml})$, 8cpt-cAMP (CAMP, $100 \mu \mathrm{M})$, or prostaglandin $E_{2}(P G E, 3 \mu \mathrm{M})$ in the absence and presence of AG490 $(50 \mu \mathrm{M})$. Values represent means \pm S.E.M. $* P<0 \cdot 01$ when compared with the corresponding control value by Student's $t$-test.

protein expression. Based on the densitometry analysis, the PRL-R/ $\beta$-actin ratio was significantly decreased from $5 \cdot 67 \pm$ 0.79 in the standard medium to $1 \cdot 15 \pm 0 \cdot 09(P<0 \cdot 05, n=4)$ in the serum-free medium. Treatment with $17 \beta$-estradiol increased the PRL-R/ $\beta$-actin ratio by twofold to $2 \cdot 35 \pm 0 \cdot 12$.

\section{Discussion}

A previous study in mouse mammary epithelial cells demonstrated that the PRL-induced increase in Isc was predominately mediated by $\mathrm{Na}^{+}$absorption (Mainoya et al. 1974). However, in another study in the mouse mammary epithelial cell line $\mathrm{HC11}$, it was $\mathrm{Cl}^{-}$transport that was acutely stimulated by PRL (Selvaraj et al. 2000). Using cultured porcine endometrial epithelial cells that possessed the machinery for $\mathrm{Na}^{+}$and $\mathrm{Cl}^{-}$transports, we showed that PRL acutely stimulated anion secretion without affecting $\mathrm{Na}^{+}$ absorption. This was further supported by the findings that the PRL-induced increase in Isc was blocked by $\mathrm{Cl}^{-}$channel 

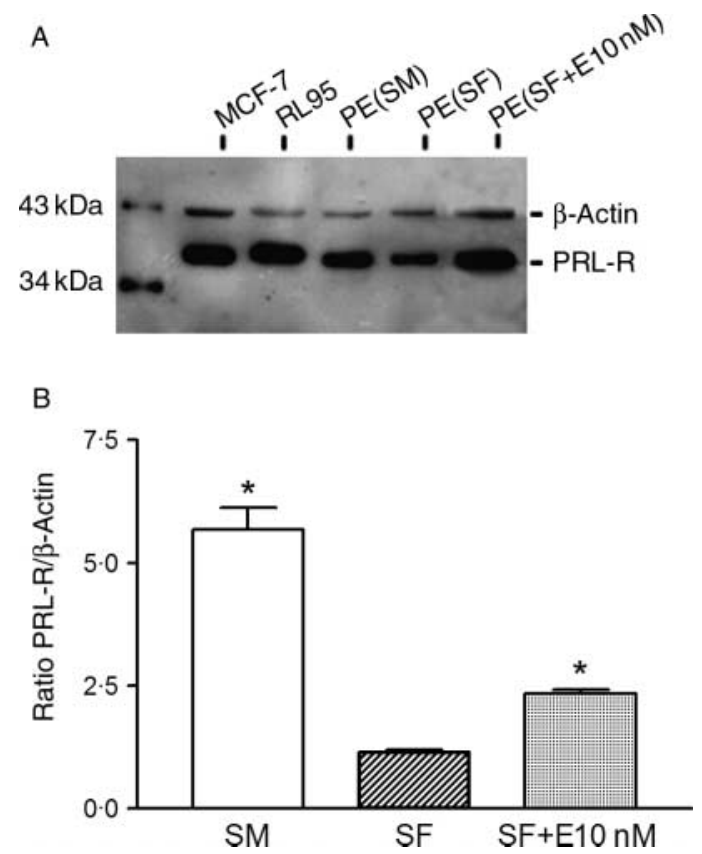

Figure 6 Expression of PRL receptor protein in porcine endometrial epithelial cells. (A) Western blot analysis of PRL receptor (PRL-R). A $36 \mathrm{kDa}$ band of PRL-R was detected in human mammary gland cancer cell MCF-7, human endometrial cancer cell RL-95, and porcine endometrial epithelial cells (PE) under standard medium (SM), serum-free medium (SF) alone, or supplemented with $10^{-8} \mathrm{M}$ $17 \beta$-estradiol (SF+E $10 \mathrm{nM}$ ). The internal control of $43 \mathrm{kDa}$ band of $\beta$-actin was also detected in all samples. (B) Bar graph illustrating the ratio of PRL-R to $\beta$-actin protein expression in the endometrial epithelial cells, based on the densitometry of immunoblots obtained from SM, SF, and SF+E10 nM $(n=4)$. Values represent means \pm S.E.M. ${ }^{*} P<0 \cdot 05$ when compared with the serum-free medium condition by Student's $t$-test.

blockers, NPPB, DPC, and DIDS, but not by $\mathrm{Na}^{+}$channel blocker, amiloride. In addition, the basolateral pretreatment with bumetanide, a blocker of $\mathrm{Na}^{+}-\mathrm{K}^{+}-2 \mathrm{Cl}^{-}$cotransporter, or replacement of $\mathrm{Cl}^{-}$or $\mathrm{HCO}_{3}^{-}$significantly inhibited the PRL-stimulated Isc. PRL added to the basolateral solution of the high-resistance monolayer produced a greater increase in the Isc response than when added to the apical solution, suggesting that PRL receptors were predominately located at the basolateral membrane. Western blot analysis revealed the expression of a $36 \mathrm{kDa}$ protein band, which corresponded to the short form of PRL-R, indicating the role of this PRL receptor isoform in the mediation of transepithelial anion secretion in the porcine endometrial epithelium.

The basal electrical properties of cultured epithelial cells used in the present study have been described previously (Deachapunya \& O'Grady 1998). Under the basal condition, these cells exhibited substantial Isc that was due to a greater $\mathrm{Cl}^{-}$secretion than $\mathrm{Na}^{+}$absorption. Application of PRL produced a concentration-dependent increase in the anion transport with a maximal effect seen at $1 \mu \mathrm{g} / \mathrm{ml} \mathrm{PRL}$ and an $\mathrm{EC}_{50}$ value of $120 \mathrm{ng} / \mathrm{ml}$. In addition, the maximal PRL response observed within 3-5 min after application, implied a non-genomic action. At PRL concentration of $1 \mu \mathrm{g} / \mathrm{ml}$, which could be considered a hyperprolactinemic level, PRL was also found to maximally stimulate $\mathrm{Cl}^{-}$transport in the mammary epithelial HC11 cells (Selvaraj et al. 2000). This effective concentration of PRL was comparable with the circulating levels during pregnancy and lactation in the human and the rat (Handwerger \& Freemark 1987, Arbogast \& Voogt 1998). Like in many other epithelia, $\mathrm{Cl}^{-}$secretion across the endometrial epithelial cells requires activation of the apical membrane $\mathrm{Cl}^{-}$channels and the basolateral membrane $\mathrm{K}^{+}$channels with the basolateral $\mathrm{Na}^{+}-\mathrm{K}^{+}-$ $2 \mathrm{Cl}^{-}$cotransporters serving as the $\mathrm{Cl}^{-}$loading step. Since two types of $\mathrm{Cl}^{-}$channels, cAMP-activated cystic fibrosis transmembrane conductance regulator (CFTR) and $\mathrm{Ca}^{2+}$ activated $\mathrm{Cl}^{-}$channels have been identified in a variety of epithelia including endometrial epithelial cells (Deachapunya \& O'Grady 1998, Palmer-Densmore et al. 2002), NPPB and DPC, inhibitors of anion channels including CFTR, and DIDS, an inhibitor of $\mathrm{Ca}^{2+}$-activated $\mathrm{Cl}^{-}$channels, were used to elucidate PRL action. As the present results showed that the PRL-induced increase in Isc was nearly completely inhibited by DPC and NPPB, it was most likely that CFTR was the primary target of the PRL-stimulated $\mathrm{Cl}^{-}$secretion. However, the $40 \%$ inhibition of the PRL-stimulated Isc by DIDS indicated that the $\mathrm{Ca}^{2+}$-activated $\mathrm{Cl}^{-}$channels may also be partially involved in the PRL activation of $\mathrm{Cl}^{-}$ secretion. In addition, the PRL-stimulated increase in Isc was also diminished by bumetanide, an inhibitor of $\mathrm{Na}^{+}-\mathrm{K}^{+}-$ $2 \mathrm{Cl}^{-}$cotransporter, which was not surprising since the bumetanide-sensitive $\mathrm{Cl}^{-}$uptake probably served as the $\mathrm{Cl}^{-}$ loading step for PRL-stimulated $\mathrm{Cl}^{-}$secretion. The finding that Isc response to PRL was abolished in the $\mathrm{Cl}^{-}$free solution further confirmed the PRL activation of $\mathrm{Cl}^{-}$secretion. Since the electronic $\mathrm{HCO}_{3}^{-}$secretion used the cAMP- and $\mathrm{Ca}^{2+}$ activated $\mathrm{Cl}^{-}$channels (Illek et al. 1999), a marked reduction of Isc response to PRL in the $\mathrm{HCO}_{3}^{-}$free solution suggested a substantial contribution of $\mathrm{HCO}_{3}^{-}$to the PRL-induced increase in Isc. Altogether, the results suggest a possible involvement of $\mathrm{Cl}^{-}-\mathrm{HCO}_{3}^{-}$exchangers as well as $\mathrm{Na}^{+}-$ $\mathrm{Na}^{+}-\mathrm{HCO}_{3}^{-}$cotransporters in the PRL-dependent $\mathrm{HCO}_{3}^{-}$ secretion. However, it was noted that the replacement of $\mathrm{HCO}_{3}^{-}$itself, could have produced the intracellular acidification, which could affect the transport pathways or the signaling mechanisms that regulate anion secretion. Taken together, it could be stated that PRL-induced anion secretion by stimulating the apical $\mathrm{Cl}^{-}$efflux through CFTR as the major channel type and through some $\mathrm{Ca}^{2+}$-activated $\mathrm{Cl}^{-}$ channels, concurrently with the increase in the basolateral $\mathrm{Cl}^{-}$uptake through the bumetanide-sensitive $\mathrm{Na}^{+}-\mathrm{K}^{+}-$ $2 \mathrm{Cl}^{-}$cotransporter. Although not being investigated in this study, the basolateral $\mathrm{K}^{+}$channels that provide the driving force for $\mathrm{Cl}^{-}$exit across the apical membrane, could also be a target of PRL action, and are subject to further investigation.

Several signaling pathways mediating the multiple actions of PRL have been demonstrated in a variety of tissues with the 
JAK-STAT pathway being most extensively studied. Previous evidence of the phosphorylation of JAK2, STAT1, and STAT5 in response to PRL stimulation in the human endometrium (Jabbour et al. 1998) and the PRL-stimulated $\mathrm{Cl}^{-}$transport through the JAK2 cascade pathway in mouse mammary epithelial cell line HC11 (Selvaraj et al. 2000) suggested that JAK2 is a likely mediator of PRL-stimulating effect on the anion transport in the porcine endometrial epithelial cells. In the present study, pretreatment with AG490, an inhibitor of JAK2 activity inhibited both the basal Isc and the PRL-induced increase in Isc. Regarding the basal Isc, since the basal Isc of the cultured porcine endometrial epithelial cells has been shown to be generated mainly by $\mathrm{Cl}^{-}$secretion (Deachapunya \& O'Grady 1998), the fact that AG490 could inhibit the basal Isc within 10 min suggested that a constitutive JAK2 activity was responsible for the basal active $\mathrm{Cl}^{-}$secretion. Although no direct association between JAK2 activity and $\mathrm{Cl}^{-}$transport mechanism has been reported, the fact that tyrosinephosphorylated proteins could regulate the basal $\mathrm{Cl}^{-}$secretion in human colonic epithelial cell line, T84 (Uribe et al. 1996) suggested that the JAK2 inhibitors inhibited $\mathrm{Cl}^{-}$secretion by interfering with the tyrosine phosphorylation of the regulatory transport proteins. Furthermore, based on the findings that i) $\mathrm{Cl}^{-}$secretion could still be activated by 8 cpt-cAMP in the presence of JAK2 inhibitor, ii) the inhibition of the basal Isc did not affect the PGE2-stimulated Isc response, and iii) the PGE2stimulated $\mathrm{Cl}^{-}$secretion was via the cAMP-dependent pathway (Deachapunya \& O'Grady 1998), it is likely that the cAMP-dependent $\mathrm{Cl}^{-}$secretion did not involve JAK2 pathway.

In contrast to the PGE2-stimulated $\mathrm{Cl}^{-}$secretion, the PRL-stimulated $\mathrm{Cl}^{-}$secretion was probably mediated by the JAK2 pathway because the PRL-induced increase in Isc was significantly inhibited by AG490. These findings were consistent with a report of AG490 blocking phosphorylation of STAT5 and PRL-induced $\mathrm{Cl}^{-}$secretion, but not the PGE1-induced $\mathrm{Cl}^{-}$secretion in mouse mammary cell line (Selvaraj et al. 2000). The effect of AG490 was more specific to PRL action, since tyrosine kinase inhibitor genistein had no effect on the PRL-stimulated Isc (data not shown).

PRL-R and its mRNA have been identified in human glandular epithelial and stromal cells (Jabbour et al. 1998, Tseng \& Zhu 1998). Two isoforms of PRL-R, short and long, have been identified in several rat tissues including liver, ovary, thymus, and spleen (Gunes \& Mastro 1996, Telleria et al. 1997). In the present study, we examined the expression of PRL-R protein in the endometrial epithelial cells by western blot analysis. The monoclonal antibody used in the present study detected protein with molecular mass of about $36 \mathrm{kDa}$, which corresponded to the short form of the PRL-R, similar to the predominant short isoforms expressed in the rat spleen and brain (Shingo et al. 2003). By contrast, the long form of PRL$\mathrm{R}$ is the major receptor isoforms in the rat liver and mammary gland (Jahn et al. 1991, Selvaraj et al. 2000). Although at least two isoforms of PRL-R mRNA have been found in the reproductive tissues (Telleria et al. 1997), the present data indicated that the short form PRL-R was the functional
PRL-R in the porcine endometrial epithelial cells, and that the PRL-stimulated $\mathrm{Cl}^{-}$secretion in the porcine endometrial epithelial cells was mediated through the short form of PRL receptors located predominately at the basolateral membrane.

Generally, PRL is synthesized by the decidualized endometrial stromal cells during the late secretory phase of the menstrual cycle and throughout pregnancy. The level of PRL is apparently much higher in the blood and amniotic fluid during pregnancy (Golander et al. 1978, Daly et al. 1983). After conception, a continuous increase in PRL production in the decidual cells leads to an accumulation of PRL in the amniotic fluid up to $2-3 \mu \mathrm{g} / \mathrm{ml}$ (Golander et al. 1978, Daly et al. 1983). Concomitantly, the PRL receptor expression and its mRNA are up-regulated toward the secretory phase of the menstrual cycle (Jabbour et al. 1998, Jones et al. 1998) and maintained throughout pregnancy (Maaskant et al. 1996). The level of PRL receptor mRNA is much higher in the glandular cells than in the stromal cells (Jabbour et al. 1998, Jones et al. 1998). Although the exact role of PRL in the human endometrium remains to be clarified, the pattern of secretion and expression supports a role of PRL in implantation and placentation. In agreement with those reports, the presence of PRL-R protein that was up-regulated by $17 \beta$-estradiol (Fig. 6) in the cultured porcine endometrial epithelial cells strongly suggested the physiological role of PRL in pregnancy. This speculation was consistent with the report that the blastocyst implantation and the maintenance of pregnancy were impaired in the PRL and PRL-R knockout mice (Jikihara et al. 1996). The next question is what is the exact role of PRL in the pregnant uterus. It is known that specific concentrations of electrolytes and $\mathrm{pH}$ within the uterine lumen are important for implantation and embryo development. In the rhesus monkey, PRL has been shown to regulate the amniotic and fetal extracellular fluid and electrolyte balance by decreasing the water flux from the amniotic side of the fetal membrane (Josimovich et al. 1977). Concomitant with the present finding of PRL role in the stimulation of anion secretion across the endometrial epithelial cells, and that active secretion of $\mathrm{Cl}^{-}$and $\mathrm{HCO}_{3}^{-}$provides the driving force for fluid secretion and the regulation of luminal fluid $\mathrm{pH}$, it is likely that PRL exerts endocrine and paracrine actions to regulate the volume and composition of the fluid within the uterine cavity, thus providing an optimal condition for implantation and development of the embryo.

In conclusion, this study shows for the first time the regulation of the transepithelial anion secretion by PRL in the endometrium. The results showed that PRL acutely stimulated anion secretion across the porcine endometrial epithelial cells through the short isoform of PRL receptor and the JAK-STAT-dependent pathway. The PRL-stimulated anion secretion was mostly a result of the activation of DPCand NPPB-sensitive $\mathrm{Cl}^{-}$channels, and bumetanide-sensitive $\mathrm{Na}^{+}-\mathrm{K}^{+}-2 \mathrm{Cl}^{-}$cotransport. Further investigation is required to define the physiological and pharmacological significance of PRL action in the endometrium. In addition, the PRL-signaling mechanisms, i.e. intracellular $\mathrm{Ca}^{2+}$, cAMP, or other signaling molecules remain to be elucidated. 


\section{Acknowledgements}

The authors wish to thank Miss Norathee Buathong for her help with primary cell preparation and some of the experiments, and Dr Narattaphol Charoenphandhu for his valuable comments of the manuscript. This work was fully supported by the Thailand Research Fund (Contract grant number: TRA4780008) awarded to N M. The authors declare that there is no conflict of interest that would prejudice the impartiality of this scientific work.

\section{References}

Anderson MP, Sheppard DN, Berger HA \& Welsh MJ 1992 Chloride channels in the apical membrane of normal and cystic fibrosis airway and intestinal epithelia. American Journal of Physiology 263 L1-L14.

Arbogast LA \& Voogt JL 1998 Endogenous opioid peptides contribute to suckling-induced prolactin release by suppressing tyrosine hydroxylase activity and messenger ribonucleic acid levels in tuberoinfundibular dopaminergic neurons. Endocrinology 139 2857-2862.

Bern HA 1975 Prolactin and osmoregulation. American Zoologists 15 937-949.

Bisbee CA, Machen TE \& Bern HA 1979 Mouse mammary epithelial cells on floating collagen gels: transepithelial ion transport and effects of PRL. PNAS 76 536-540.

Bole-Feysot C, Goffin V, Edery M, Binart N \& Kelly PA 1998 Prolactin (PRL) and its receptor: actions, signal transduction pathways and phenotypes observed in PRL receptor knockout mice. Endocrine Reviews 19 225-268.

Chan HC, Liu CQ, Fong SK, Law SH, Wu LJ, So E, Chung YW, Ko WH \& Wong PYD 1997 Regulation of $\mathrm{Cl}^{-}$secretion by extracellular ATP in cultured mouse endometrial epithelium. Journal of Membrane Biology 156 45-52.

Charoenphandhu N \& Krishnamra N 2007 Prolactin is an important regulator of intestinal calcium transport. Canadian Journal of Physiology and Pharmacology 85 569-581.

Clevenger CV \& Kline JB 2001 Prolactin receptor signal transduction. Lupus $10706-718$

Daly DC, Maslar IA \& Riddick DH 1983 Prolactin production during in vitro decidualization of proliferative endometrium. American Journal of Obstetrics and Gynecology 145 672-678.

Deachapunya C \& O'Grady SM 1998 Regulation of chloride secretion across porcine endometrial epithelial cells by prostaglandin $\mathrm{E}_{2}$. Journal of Physiology 508 31-47.

Deachapunya C \& O'Grady SM 2001 EGF regulates the transition from basal sodium absorption to anion secretion in cultured endometrial epithelial cells. Journal of Cell Physiology 186 243-250.

Deachapunya C, Palmer-Densmore M \& O’Grady SM 1999 Insulin stimulates transepithelial sodium transport by activation of a protein phosphatase that increases Na-K ATPase activity in endometrial epithelial cells. Journal of General Physiology 114 561-574.

Fong SK, Liu CQ \& Chan HC 1998 Cellular mechanisms of adrenalinestimulated anion secretion by the mouse endometrium epithelium. Biology of Reproduction 59 1342-1348.

Freeman ME, Kanyicsky B, Lerant A \& Nagy G 2000 Prolactin: structure, function, and regulation of secretion. Physiological Reviews 80 1523-1631.

Golander A, Hurley T, Barrett J, Hizi A \& Handwerger S 1978 Prolactin synthesis by human chorion decidual tissue: a possible source of prolactin in the amniotic fluid. Science 202 311-313.

Gubbay O, Critchley HOD, Bowen JM, King A \& Jabbour HN 2002 Prolactin induces ERK phosphorylation in epithelial and CD56+ natural killer cells of the human endometrium. Journal of Clinical Endocrinology and Metabolism 87 2329-2335.

Gunes H \& Mastro AM 1996 Prolectin receptor gene expression in rat splenocytes and thymocytes from birth to adulthood. Molecular and Cellular Endocrinology 117 41-52.

Handwerger S \& Freemark M 1987 Role of placental lactogen and prolactin in human pregnancy. Advances in Experimental Medicine and Biology 219 399-420.
Illek B, Tam AW, Fischer H \& Machen TE 1999 Anion selectivity of apical membrane conductance of Calu 3 human airway epithelium. Pflügers Archiv 437 812-822.

Jabbour HN, Critchley HO \& Boddy SC 1998 Expression of functional prolactin receptors in nonpregnant human endometrium: janus kinase-2, signal transducer and activator of transcription-1 (STAT1), and STAT5 proteins are phosphorylated after stimulation with prolactin. Journal of Clinical Endocrinology and Metabolism 83 2545-2553.

Jahn GA, Edery M, Belair L, Kelly PA \& Djiane J 1991 Prolactin receptor gene expression in rat mammary gland and liver during pregnancy and lactation. Endocrinology 128 2976-2984.

Jantarajit W, Thongon N, Pandaranandaka J, Teerapornpuntakit J, Krishnamra N \& Charoenphandhu N 2007 Prolactin-stimulated transepithelial calcium transport in duodenum and Caco-2 monolayer are mediated by the phosphoinositide 3-kinase pathway. American Journal of Physiology. Endocrinology and Metabolism 293 372-384.

Jikihara H, Kessler CA, Cedars MI \& Bra AK 1996 Up-regulation of the human prolactin receptor in the endometrium. Journal of Endocrinology 5 157-162.

Jones RL, Critchley HO, Brooks J, Jabbour HN \& McNeilly AS 1998 Localization and temporal expression of prolactin recptor in human endometrium. Journal of Clinical Endocrinology and Metabolism 83 258-262.

Josimovich JB, Merisko K \& Boccella L 1977 Amniotic prolactin control over amniotic and fetal extracellular fluid water and electrolytes in the rhesus monkey. Endocrinology 100 564-570.

Kelly PA, Djiane J, Postel-Vinay MC \& Edery M 1991 The prolactin/growth hormone receptor family. Endocrine Reviews 12 235-251.

Linzell JL, Peaker M \& Taylor JC 1975 The effects of prolactin and oxytocin on milk secretion and on the permeability of the mammary epithelium in the rabbit. Journal of Physiology 253 547-563.

Maaskant RA, Bogic LV, Gilger S, Kelly PA \& Bryant-Greenwood GD 1996 The human prolactin receptor in the fetal membranes, decidua, and placenta. Journal of Clinical Endocrinology Metabolism 81 396-405.

Mainoya JR, Bern HA \& Regan JW 1974 Influence of ovine prolactin on transport of fluid and sodium chloride by the mammalian intestine and gall bladder. Journal of Endocrinology 63 311-317.

Matthews CJ, Thomas EJ, Redfern CPF \& Hirst BH 1993 Ion transport by human endometrium in vitro. Human Reproduction 8 1510-1575.

Palmer-Densmore M, Deachapunya C \& O'Grady SM 2002 UTP-dependent inhibition of $\mathrm{Na}$ absorption requires activation of $\mathrm{PKC}$ in endometrial epithelial cells. Journal of General Physiology 120 897-906.

Sakamoto T \& McCormick SD 2006 Prolactin and growth hormone in fish osmoregulation. General and Comparative Endocrinology 147 24-30.

Selvaraj NG, Omi E, Gibori G \& Rao MC 2000 Janus kinase 2 (JAK2) regulates prolactin-mediated chloride transport in mouse mammary epithelial cells through tyrosine phosphorylation of $\mathrm{Na}^{+}-\mathrm{K}^{+}-2 \mathrm{Cl}^{-}$ cotransporter. Molecular Endocrinology 14 2054-2065.

Shingo T, Gregg C, Enwere E, Fujikawa H, Hassam R, Geary C, Cross JC \& Weiss S 2003 Pregnancy-stimulated neurogenesis in the adult female forebrain mediated by prolactin. Science 299 117-120.

Telleria CM, Parmer TG, Zhong L, Clarke DL, Albarracin CT, Duan WR, Linzer DI \& Gibori G 1997 The different forms of the prolactin receptor in the rat corpus luteum: developmental expression and hormonal regulation in pregnancy. Endocrinology 138 4812-4820.

Tseng L \& Zhu HH 1998 Progestin induces prolactin receptor in human endometrial stromal cells. Journal of the Society for Gynecologic Investigation 5 149-155.

Uribe JM, Keely SJ, Traynor-Kaplan AE \& Barrett KE 1996 Phosphatidylinositol 3-kinase mediates the inhibitory effect of epidermal growth factor on calcium-dependent chloride secretion. Journal of Biological Chemistry 271 $26588-26595$.

Vetter AE \& O'Grady SM 1996 Mechanisms of electrolyte transport across the endometrium I. Regulation by PGF2 and cAMP. American Journal of Physiology. Cell Physiology 270 663-672.

Received in final form 29 March 2008

Accepted 4 April 2008

Made available online as an Accepted Preprint 4 April 2008 